\title{
ANALISIS SISTEM PENGENDALIAN INTERN DAN PEMANFAATAN IT GOVERNANCE TERHADAP KEANDALAN LAPORAN KEUANGAN PEMERINTAH DAERAH KABUPATEN MINAHASA TENGGARA MENGGUNAKAN FRAMEWORK COBIT (Control Objectives For Information And Related Technology)
}

\author{
Halens Ryanlie Ole \\ Grace Nangoi \\ Heince R. N. Wokas \\ Fakultas Ekonomi dan Bisnis Magister Akuntansi \\ Universitas Sam Ratulangi Manado \\ Email: ryanlie.ole@gmail.com
}

\begin{abstract}
The purpose of this study was to assess the internal control system in a number of "SKPD" in Southeast Minahasa Regency and check also the utilization of IT Governance at the "SKPD". This study uses the COBIT framework to analyze the system of internal control and utilization of IT Governance in sectors in Southeast Minahasa Regency.

The method used in this research using descriptive method by distributing questionnaires purposive sampling to target treasurer, operator, or financial administration officials are determined randomly. Obtained data is then processed and dideskriptifkan by researchers thus a detailed explanation of the study.

The results showed that the Financial Statements To improve the reliability of the Local Government needed improvements in terms of control and monitoring activities. Meanwhile, IT Governance are not yet standardized, but have had the procedure. The most mature component is information architecture while most adults are communication objectives and management direction.
\end{abstract}

Keywords : Internal Control System, SKPD, and IT Governance

\section{PENDAHULUAN}

\subsection{Latar Belakang}

Sejak Pemerintah Republik Indonesia memberlakukan otonomi daerah dengan dikeluarkannya Undang-Undang Nomor 22 Tahun 1999 tentang Pemerintah Daerah (kemudian menjadi UndangUndang Nomor 32 Tahun 2004), maka setiap daerah diberikan kewenangan untuk mengatur urusan pemerintahannya sendiri, termasuk didalamnya mengenai keuangan daerah. Sejalan dengan itu Pemerintah Republik Indonesia telah melakukan reformasi pengelolaan keuangan negara dengan mengeluarkan Undang-Undang bidang keuangan Negara (UU Nomor 17 Tahun 2003 tentang Keuangan Negara, UU No 1 Tahun 2004 dan UU No 15 tentang Pemeriksaan Pertanggungjawaban Keuangan Negara), tata cara pelaporan keuangan pemerintah yang dirasakan kurang transparan dan akuntabel telah berubah, karena sebelumnya laporan keuangan tersebut belum sepenuhnya disusun mengikuti standar akuntansi pemerintahan yang sejalan dengan standar akuntansi sektor publik yang diterima secara internasional.

Sistem Pengendalian Intern (SPI) di lingkungan instansi pemerintah dikenal sebagai suatu sistem yang diciptakan untuk mendukung upaya agar penyelenggaraan kegiatan pada instansi pemerintahan dapat mencapai tujuannya secara efisien dan efektif, dimana pengelolaan keuangan Negara dapat dilaporkan secara andal, asset negara dapat dikelola dengan aman, dan tentunya mendorong ketaatan terhadap peraturan perundang-undangan. SPI dalam penerapannya harus senantiasa memperhatikan norma keadilan dan kepatutan serta mempertimbangkan ukuran, kompleksitas dan sifat dari tugas dan fungsi instansi pemerintah (Penjelasan umum PP No 60 Tahun 2008). 
Sistem Pengendalian Intern berjalan efektif bila dua unsur yaitu kemampuan sumber daya manusia (SDM) dan teknologi informasi saling mendukung satu sama lain. Pada sebuah dokumen yang diterbitkan oleh The Committee of Sponsoring Organizations of the Treadway Commission (COSO), dua puluh prinsip kunci (key principles) pengendalian internal dalam rangka pelaporan keuangan. Teknologi Informasi merupakan termasuk didalam dua puluh prinsip kunci yang merupakan bagian dari Aktivitas Pengendalian (Control Activities). Teknologi Informasi - Pengendalian teknologi informasi, bila memungkinkan, didesain dan diimplementasikan untuk mendukung pencapaian tujuan pelaporan keuangan.

Pada Pemaparan Anwar Nasution dalam buku Perbaikan Pengelolaan Keuangan Negara Dalam Era Reformasi, beliau menyampaikan ada 10 (sepuluh) Kelemahan Sistem Pengendalian Internal yang sangat mempengaruhi Pemerintah Pusat dan Pemerintah Daerah untuk mendapatkan Opini Wajar Tanpa Pengecualian. Salah satunya adalah Sinkronisasi Sistem Aplikasi Teknologi Komputer yang belum terintegrasi (IT Related) dan kompatible antara satu dengan lainnya. (Anwar Nasution, 2008:13)

Berdasarkan latar belakang yang telah diuraikan diatas, peneliti ingin melihat bagaimana analisis sebuah sistem pengendalian intern pada pemerintah Kabupaten Minahasa Tenggara apakah berjalan sesuai dengan prinsip-prinsip pengendalian internal dengan memanfaatan teknologi informasi pada kualitas penyajian Laporan Keuangan Pemerintah Daerah (LKPD) yang sejak tahun 2008 - 2011 selalu mendapatkan opini disclaimer dari Badan Pemeriksa Keuangan (BPK) dengan menggunakan CobiT Framework. Maka peneliti mengambil judul Analisis Sistem Pengendalian Intern Dan Pemanfaatan IT Governance Terhadap Keandalan Laporan Keuangan Pemerintah Daerah Kabupaten Minahasa Tenggara Menggunakan Framework Cobit (Control Objectives For Information And Related Technology)".

\subsection{Rumusan Masalah}

Berdasarkan uraian latarbelakang masalah diatas, maka penelitian ini merumuskan masalah sebagai berikut.

1. Bagaimana pelaksanaan Sistem Pengendalian Intern dalam menghasilkan keandalan Laporan Keuangan Pemerintah Daerah dinilai dari kerangka kerja CobiT pada Kabupaten Minahasa Tenggara?

2. Bagaimana pemanfaatan IT Governance terhadap keandalan Laporan Keuangan Pemerintah Daerah dinilai dari kerangka kerja CobiT pada Kabupaten Minahasa Tenggara?

\subsection{Batasan Masalah}

1. Lingkup dari penelitian ini dibatasi pada menilai Sistem Teknologi Informasi yang sudah dimanfaatkan oleh Pemerintah Kabupaten Minahasa Tenggara untuk menghasilkan Laporan Keuangan Pemerintah Daerah yang andal.

2. Lingkup Penelitian ini hanya menilai 1 domain CobiT 4.1 PO Plan and Organise (Perencanaan dan Pengorganisasian).

\subsection{Tujuan Penelitian}

Berdasarkan rumusan masalah di atas, maka tujuan penelitian ini untuk:

1. Menganalisis pelaksanaan Sistem Pengendalian Intern dalam menghasilkan keandalan Laporan Keuangan Pemerintah Daerah dinilai dari kerangka kerja CobiT.

2. Menganalisis seberapa besar pemanfaatan IT Governance terhadap keandalan Laporan Keuangan Pemerintah Daerah dinilai dari kerangka kerja CobiT.

\subsection{Manfaat Penelitian}

Hasil penelitian ini diharapkan dapat memberikan manfaat sebagai berikut:

1. Bagi pemegang kebijakan, dalam hal ini pemerintah daerah, hasil penelitian ini diharapkan dapat memberikan informasi mengenai sistem pengendalian intern dan pemanfaatan IT Governance, 
sehingga akan dapat dimanfaatkan dalam upaya peningkatan keandalan laporan keuangan daerah di Pemerintah Kabupaten Minahasa Tenggara.

2. Bagi Inspektorat dan Seluruh Kepala Satuan Kerja Perangkat Daerah (SKPD), sebagai masukan dalam mendukung pelaksanaan otonomi daerah khususnya peranan Inspektorat sebagai aparat pengawasan intern pemerintah (APIP) dan Seluruh Kepala Satuan Kerja Perangkat Daerah (SKPD) sebagai Pimpinan Instansi Pemerintah menciptakan sistem pengendalian intern yang baik demi tercapainya efektivitas dan efisiensi pencapaian tujuan penyelenggaraan pemerintahan negara, keandalan pelaporan keuangan, pengamanan aset negara, dan ketaatan terhadap peraturan perundang-undangan.

3. Bagi akademisi, memberikan kontribusi pengembangan literatur akuntansi sektor publik di Indonesia terutama sistem pengendalian manajemen di sektor publik. Selain itu penelitian ini diharapkan dapat menambah referensi dan mendorong dilakukannya penelitian-penelitian akuntansi sektor publik. Hasil penelitian ini juga diharapkan akan dapat memberikan sumbangan bagi penelitian berikutnya.

\section{TINJAUAN PUSTAKA}

\subsection{Landasan Teori}

\subsubsection{Teori Keagenan}

Kewajiban pemanfaatan teknologi informasi oleh Pemerintah dan Pemerintah Daerah diatur dalam Hubungan keagenan merupakan suatu kontrak dimana satu orang atau lebih (prinsipal) memerintah orang lain (agen) untuk melakukan suatu jasa atas nama prinsipal serta memberi wewenang kepada agen untuk membuat keputusan yang terbaik bagi prinsipal (Jensen dan Meckling, 1976).

\subsubsection{Teori Kepatuhan}

Berdasarkan perspektif normatif maka sudah seharusnya bahwa teori kepatuhan ini dapat diterapkan di bidang akuntansi Apalagi kepatuhan entitas pelaporan dalam menyampaikan laporan pertanggungjawaban berupa laporan keuangan merupakan suatu hal yang mutlak dalam memenuhi kepatuhan terhadap pengungkapan informasi dalam laporan keuangan yang sesuai dengan Standar Akuntansi Pemerintahan (Faristina, 2011).

\subsubsection{Teori Atribusi}

Dalam teori atribusi menjelaskan bahwa tindakan seorang pemimpin maupun orang yang diberikan wewenang dipengaruhi oleh atribut penyebab (Green and Mitchell, dalam Gifandi, 2011). Dengan adanya pengendalian internal maka tindakan tidak etis akan berkurang. Jika keefektifan pengendalian internal tinggi maka perilaku tidak etis akan menurun.

\subsection{Sistem Pengendalian Intern}

Keandalan Pelaporan Keuangan adalah bagian dari tujuan Sistem Pengendalian Intern.Menurut COSO (Committee of Sponsoring Organizations of the Treadway Commission) (2013) ada tiga tujuan Sistem Pengendalian Intern antara lain: 1. Realibility of financial reporting; 2. Compliance with laws and regulations; and 3. Effective and efficient operations

Sesuai dengan PP Nomor 60 Tahun 2008, SPIP terdiri dari lima unsur, yaitu: 1. Lingkungan Pengendalian, 2. Penilaian risiko, 3. Kegiatan pengendalian, 4. Informasi dan komunikasi, 5. Pemantauan pengendalian intern

\subsection{Pemanfaatan IT Governance}

Teknologi informasi meliputi komputer (mainframe, mini, micro), perangkat lunak (software), database, jaringan (internet, intranet), electronic commerce, dan jenis lainnya yang berhubungan dengan teknologi (Wilkinson et al., 2000).

Kewajiban pemanfaatan teknologi informasi oleh Pemerintah dan Pemerintah Daerah diatur dalam Peraturan Pemerintah No. 56 Tahun 2005 tentang Sistem Informasi Keuangan Daerah yang merupakan pengganti dari PP No. 11 Tahun 2001 tentang Informasi Keuangan Daerah.

\subsection{Keandalan Laporan Keuangan}


Peraturan Pemerintah Nomor 71 Tahun 2010 tentang Standar Akuntansi Pemerintahan pada Lampiran I menyebutkan bahwa kriteria dan unsur-unsur pembentuk kualitas informasi yang menjadikan informasi dalam laporan keuangan pemerintah mempunyai nilai atau manfaat yang disebutkan dalam Kerangka Konseptual Akuntansi Pemerintahan terdiri dari: (a) Relevan, (b) Andal, (c) Dapat dibandingkan dan (d) Dapat dipahami.

Dan pada Paragraf ke 38 disana dijelaskan bahwal Laporan Keuangan dianggap andal jika Informasi dalam laporan keuangan bebas dari pengertian yang menyesatkan dan kesalahan material, menyajikan setiap fakta secara jujur, serta dapat diverifikasi. Informasi mungkin relevan, tetapi jika hakikat atau penyajiannya tidak dapat diandalkan maka penggunaan informasi tersebut secara potensial dapat menyesatkan. Informasi yang andal memenuhi karakteristik: (a) Penyajian Jujur, (b) Dapat Diverifikasi (verifiability), (c) Netralitas

\subsection{CobiT (Control Objectives for Information and Related Technology)}

CobiT yaitu Control Objectives for Information and Related Technology adalah sebuat kerangka tata kelola IT dan merupakan sekumpulan dokumentasi dan panduan yang mengarahkan pada IT governance yang dapat membantu auditor, manajemen, dan pengguna (user) untuk menjembatani pemisah antara resiko bisnis, kebutuhan kontrol, dan permasalahan-permasalahan teknis. (Isaca, 1992)

\section{KERANGKA KONSEPTUAL PENELITIAN}

\subsection{Kerangka Konseptual Penelitian}

Untuk lebih menyederhanakan kerangka pemikiran tersebut maka dibuatlah kerangka konseptual seperti pada gambar 3.1 dibawah ini:

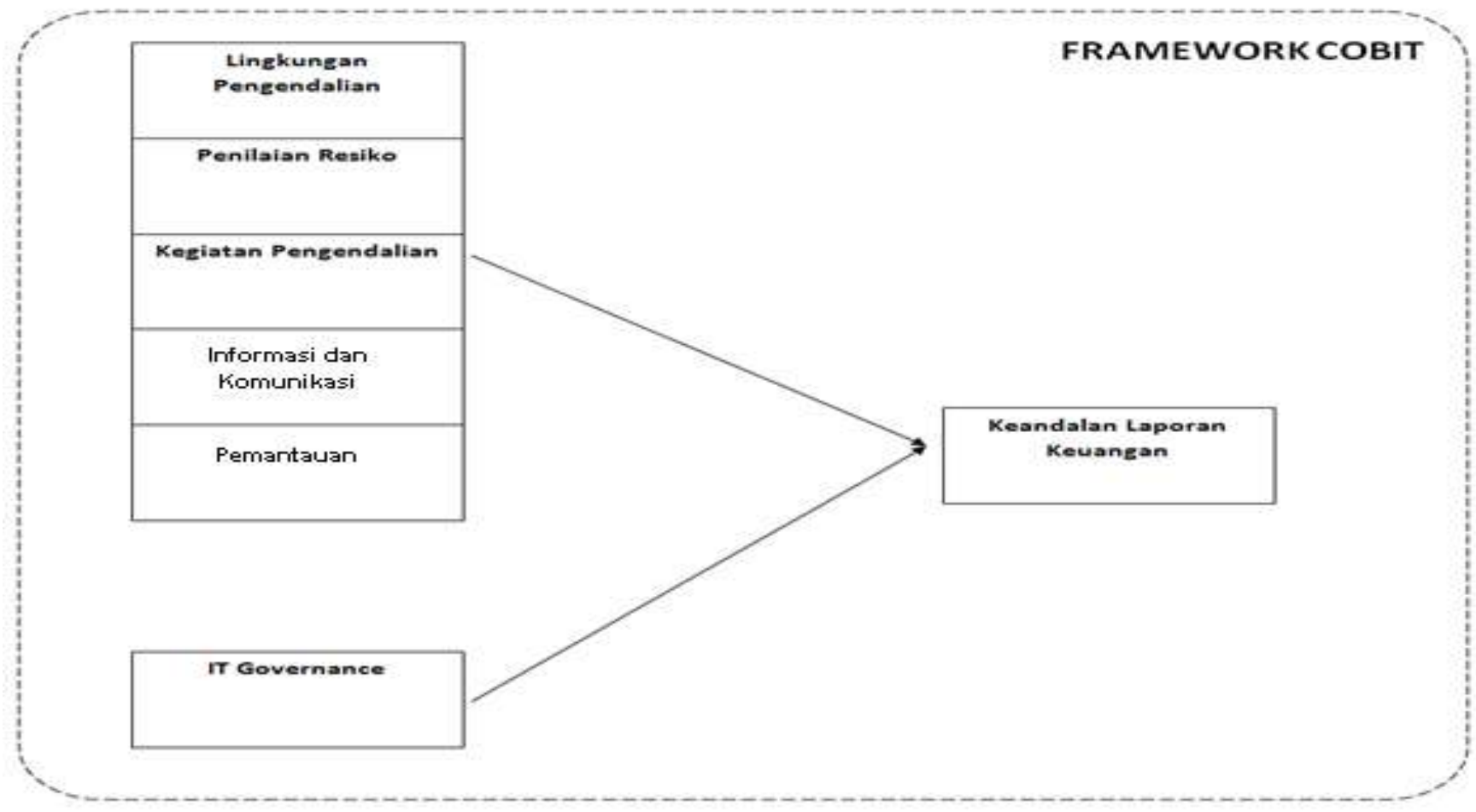

Sumber : Data Olahan (2014)

\subsection{Proposisi}

\section{Kelima Unsur Sistem Pengendalian Intern Pemerintah Mendukung Keandalan Laporan Keuangan Pemerintah Daerah}

Pengendalian intern terdiri atas lima unsur yang meliputi : (1) Control environment; (2) Risk assesment; (3) Control activities; (4) Information and communication; (5) Monitoring (COSO, 2009 ; Arens et.al., 2010 ; PP No. 60/2008). 
Melalui Peraturan Pemerintah Nomor 60 Tahun 2008 pemerintah menetapkan adanya suatu sistem pengendalian intern yang harus dilaksanakan, baik pada tingkat pemerintah pusat maupun daerah. Sistem pengendalian intern dimaksud adalah suatu proses yang integral pada tindakan dan kegiatan yang dilakukan secara terus menerus oleh pimpinan dan seluruh pegawai untuk memberikan keyakinan memadai atas tercapainya tujuan organisasi melalui kegiatan yang efektif dan efisien, keandalan pelaporan keuangan, pengamanan aset negara, dan ketaatan terhadap peraturan perundangundangan (Peraturan Pemerintah No. 60 Tahun 2008 tentang Sistem Pengendalian Intern Pemerintah). Dengan demikian pengendalian intern yang memadai akan menciptakan tercapainya kualitas laporan keuangan yang baik.

\section{IT Governance Mendukung Keandalan Laporan Keuangan Pemerintah Daerah.}

Menurut Indriasari dan Nahartyo (2008) menyatakan bahwa perkembangan teknologi informasi tidak hanya dimanfaatkan pada organisasi bisnis tetapi juga pada organisasi sektor publik, termasuk pemerintahan. Teknologi informasi menunjukkan bahwa pengolahan data dengan memanfaatkan teknologi informasi (komputer dan jaringan) memberikan banyak keunggulan baik dari sisi keakuratan/ketepatan hasil operasi maupun predikatnya sebagai mesin multiguna. Pemanfaatan teknologi informasi juga mengurangi kesalahan yang terjadi.

Kemajuan dalam teknologi komputer mempunyai dampak luar biasa pada seluruh aspek kegiatan usaha. Dalam sistem akuntansi manual, data sebagai masukan (input) diproses menjadi informasi sebagai keluaran (output) dengan menggunakan tangan. Pada sistem akuntansi yang berkomputer atau yang lebih sering disebut Pemrosesan Data Elektronik (PDE), data sebagai input juga diproses menjadi informasi sebagai output. Keuntungan yang dapat dilihat secara jelas dari penggunaan komputer ini adalah kecepatan, ketepatan, dan kemudian akuntansi (Banker et al., 2002, dikutip dari Setyawardani, 2007, h.85).

\section{Metode Penelitian}

\subsection{Jenis dan Sumber Data}

Berdasarkan sumber pengambilannya, data dibedakan atas dua, yaitu data primer dan data sekunder (Hasan , 2008, dikutip dari Iskandar, 2013, h.204)

1. Data Primer; biasanya diperoleh dengan survei lapangan yang menggunakan semua metode pengumpulan data original (Kuncoro, 2003:127). Dalam penelitian ini, data primer berupa pertanyaan peneliti dan jawaban responden melalui kuesioner yang akan dibagikan kepada responden.

2. Data Sekunder; biasanya telah dikumpulkan oleh lembaga pengumpul data dan dipublikasikan kepada masyarakat pengguna data (Kuncoro, 2003:127). Dalam penelitian ini penulis mengambil data yang terkait relevan dengan masalah yang diangkat sebagai bahan dan materi dalam pembahasan dalam proposal ini.

\subsection{Teknik Pengumpulan Data}

Sesuai dengan bentuk pendekatan penelitian kualitatif dan dalam usaha memperoleh data dan informasi yang berkenaan dengan penelitian ini untuk dijadikan sebagai bahan atau materi pembahasan, maka pengumpulan data dilakukan dengan penelitian lapangan (Field Research) yang menggunakan beberapa metode yaitu Observasi, Wawancara, Kuesioner.

\subsection{Obyek dan Waktu Penelitian}

Obyek dalam penelitian ini mengambil lokasi di Dinas Pendapatan, Pengelolaan Keuangan dan Aset Daerah (DPPKAD) Kabupaten Minahasa Tenggara dengan waktu penelitian selama , 1 tahun 1 bulan yaitu mulai bulan September 2013 sampai dengan bulan Oktober 2014.

\subsection{Populasi dan Sampel}

Populasi yang digunakan dalam penelitian ini adalah Satuan Kerja Perangkat Daerah (SKPD) di Kabupaten Minahasa Tenggara. Jumlah SKPD yang ada di Kabupaten Minahasa Tenggara sebanyak 42 SKPD. Sedangkan sampel penelitian akan dipilih dengan pendekatan purposive sampling dimana menurut Margono (2004), pemilihan sekelompok subjek dalam purposive sampling, didasarkan atas ciri-ciri tertentu yang dipandang mempunyai sangkut paut yang erat dengan ciri-ciri populasi yang 
sudah diketahui sebelumnya, sehingga unit sampel yang dihubungi disesuaikan dengan kriteriakriteria.

\subsection{Metode dan Teknik Analisis}

Metode penelitian yang digunakan dalam penelitian ini menggunakan metode deskriptif dengan cara penyebaran kuisioner kepada para responden bendahara dan operator SIMDA di setiap SKPD. Data data yang diperoleh kemudian diolah dan dideskriptifkan oleh peneliti sehingga mendapat penjelasan secara detail mengenai penelitian ini. Menurut Nazir (2007:55), "Metode deskriptif adalah metode penelitian untuk membuat gambaran mengenai situasi atau kejadian sehingga metode ini berkehendak mengadakan akumulasi data dasar belaka."

\section{HASIL PENELITIAN DAN PEMBAHASAN}

\subsection{Data Karekteristik Responden}

Sebelum hasil penelitian disajikan, terlebih dahulu dengan sederhana dijelaskan karakteristik responden. Karakteristik responden meliputi jenis kelamin, tingkat pendidikan responden, frekuensi mengikuti bimbingan teknis (bimtek).

Tabel 5.10 Karakteristik Responden berdasarkan kelamin

\begin{tabular}{|l|l|l|l|}
\hline No & $\begin{array}{l}\text { Jenis } \\
\text { Kelamin }\end{array}$ & $\begin{array}{l}\text { Jumlah } \\
\text { Responden }\end{array}$ & Presentasi \\
\hline 1 & Pria & 17 & 56,67 \\
\hline 2 & Wanita & 13 & 43,33 \\
\hline & Total & 30 & 100,00 \\
\hline
\end{tabular}

Sumber: Analisis data

Dilihat dari jenis kelamin, sebesar 56,67\% atau 17 responden berjenis kelamin pria dan sisanya sebesar $43.33 \%$ atau 27 responden berjenis kelamin wanita.

Tabel 5.11 Tingkat Pendidikan Responden

\begin{tabular}{|l|l|l|l|}
\hline No & $\begin{array}{l}\text { Pendidikan } \\
\text { Terakhir }\end{array}$ & $\begin{array}{l}\text { Jumlah } \\
\text { Responden }\end{array}$ & Presentasi \\
\hline 1 & SMA & 3 & 10,00 \\
\hline 2 & Diploma & 2 & 6,67 \\
\hline 3 & S1 & 24 & 80,00 \\
\hline 4 & S2 & 1 & 3,33 \\
\hline & Total & 30 & 100,00 \\
\hline
\end{tabular}

Sumber : Analisis data

Responden penelitian ini terdiri dari 30 orang, masing-masing mewakili satu SKPD. Dilihat dari latar pendidikan responden, mayoritas berpendidikan sarjana (S1) sebanyak 24 orang (80\%), sisanya SMK 3 orang (10\%), diploma 2 orang $(6,7 \%)$, dan magister 1 orang $(3,3 \%)$.

Dilihat dari latar pendidikan, mayoritas berlatar ekonomi manajemen yaitu 11 orang (36,7\%). Latar pendidikan yang lebih dari satu orang mencakuplah ekonomi akuntansi 3 orang, sarjana administrasi 2 orang, sarjana ekonomi 2 orang, dan sarjana ilmu kelautan 2 orang. Latar pendidikan yang masingmasing hanya satu orang adalah kesehatan lingkungan, magister manajemen, peternakan, sarjana hukum, sarjana kesehatan masyarakat, sarjana komputer, sarjana sosial, sarjana teknik, dan teknik mesin. Satu orang tidak memberikan jawaban.

Dilihat dari frekuensi Bimtek, mayoritas responden (46,7\% atau 14 orang) mengikuti dua kali bimtek. Ada 5 orang yang mengikut bimtek satu kali, 7 orang tiga kali, 1 orang empat kali, dan 1 orang enam 
kali. Hanya ada dua orang yang mengaku belum pernah mengikuti bimtek. Rata-rata adalah 2,13 dengan standar deviasi 1,167.

\section{Tabel 5.12 Frekuensi Bimtek Responden CobiT}

\begin{tabular}{|l|l|l|l|}
\hline No & $\begin{array}{l}\text { Frekuensi } \\
\text { Bimtek } \\
\text { yang } \\
\text { diikuti }\end{array}$ & $\begin{array}{l}\text { Jumlah } \\
\text { Responden }\end{array}$ & Presentasi \\
\hline 1 & 0 & 2 & 6,67 \\
\hline 2 & $1-2$ & 19 & 63,33 \\
\hline 3 & $3-4$ & 8 & 26,67 \\
\hline 4 & $5-6$ & 1 & 3,33 \\
\hline 5 & $7-8$ & 0 & 0,00 \\
\hline & Total & 30 & 100,00 \\
\hline
\end{tabular}

\section{Narasumber Wawancara}

\section{Sumber : Analisis data}

Narasumber wawancara terdiri dari dua orang. Narasumber pertama yang memberikan informasi umum tentang Penerapan IT Governance menjabat sebagai sekretaris inspektorat. Dalam satgas SPIP, beliau menjabat sebagai anggota satgas. Usia responden adalah 48 tahun, berjenis kelamin laki-laki, berlatar pendidikan Magister Sains, dan menjadi PNS sejak tahun 2002. Narasumber kedua yang memberikan informasi kontekstual mengenai situasi penerapan SPI di Kabupaten Minahasa Tenggara merupakan Sekda Kabupaten Minahasa Tenggara. Beliau juga menjadi ketua Satgas SPIP. Beliau berusia 54 tahun, berjenis kelamin laki-laki, berlatar pendidikan Magister Teknik, dan menjadi PNS sejak tahun 1993.

\subsection{Pembahasans}

\subsubsection{Penerapan Sistem Pengendalian Intern pada Kabupaten Minahasa Tenggara}

Secara keseluruhan, sistem pengendalian intern memiliki nilai rata-rata $68 \%$ yang berarti telah baik. Komponen yang paling baik adalah komponen informasi dan komunikasi (rata-rata 98\%) dan komponen lingkungan pengendalian (rata-rata $81 \%$ ). Komponen yang paling buruk adalah komponen aktivitas pengendalian (rata-rata 31\%) dan komponen pemantauan (rata-rata 59\%). Hasil ini membenarkan bahwa secara umum, dalam organisasi komponen pengendalian intern yang tergolong lemah adalah komponen pemantauan (Simonsson dan Johnson, 2006).

Kualitas hasil pengendalian intern ini menurut narasumber telah lebih baik dari sebelumnya. Berdasarkan kesaksian narasumber, opini BPK untuk laporan keuangan daerah kabupaten Minahasa Tenggara tahun 2012 adalah disclaimer, sementara untuk tahun 2013 meningkat menjadi tidak wajar (adversed), satu tingkat lebih tinggi. Kabupaten Minahasa Tenggara telah mendapat opini disclaimer dalam lima tahun sejak 2008 sehingga hal ini merupakan sebuah kemajuan. Status tidak wajar berangkat dari kesalahan pencatatan administrasi. Kesalahan ini mencakuplah kesalahan di luar kendali entitas pada dua hal. Pertama, adanya potensi kerugian pada inspektorat dan sekretariat daerah yang tidak tertib sehingga menghasilkan potensi kerugian keuangan daerah sebesar Rp 532 juta akibat tidak sesuai dengan realisasi atau peruntukan. Hal ini mencakuplah $\mathrm{Rp} 436$ juta yang diakui sebagai realisasi bank. Kedua, adanya indikasi tidak nyata pada belanja barang dan jasa sebesar sekitar Rp 2 Milyar. Indikasi ini mencakuplah belanja alat tulis kantor ( $R p \quad 875$ juta), instalasi penerangan (Rp 396 juta), dan budget makan dan minum (Rp 910 juta).

\subsubsection{Pemanfaatan IT Governance pada Kabupaten Minahasa Tenggara dari Framework COBIT}

Hasil keseluruhan evaluasi kerangka CobiT untuk IT Governance ditunjukkan pada tabel 5.23 berikut. 
Tabel 5.23

Evaluasi Keseluruhan IT Governance

\begin{tabular}{|l|l|c|}
\hline \multicolumn{1}{|c|}{ Aspek } & Average & SD \\
\hline PO 1 Define Strategic IT Plan & 2,22 & 5,87 \\
\hline PO2 Define the Information Architecture & 2,57 & 8,15 \\
\hline PO3 Determine Technological direction & 1,88 & 6,26 \\
\hline PO4 Define the IT process, Organisation and Relationship & 2,32 & 6,58 \\
\hline PO5 Manage the IT Investment & 2,12 & 6,28 \\
\hline PO6 Communicate Management Aims and Directions & 1,79 & 6,70 \\
\hline PO7 Manage IT human resource & 2,37 & 6,89 \\
\hline PO8 Manage Quality & 2,13 & 8,57 \\
\hline Mean & 2,17 & 6,91 \\
\hline
\end{tabular}

Sumber: Analisis Data

Tabel 5.23 menunjukkan bahwa pengelolaan IT Governance di SKPD Kabupaten Minahasa Tenggara secara umum memiliki skor rata-rata 2,17 yang bermakna masih belum terstandar, walaupun telah memiliki prosedur. Nilai ini sejalan dengan level repeatable but intuitive dalam model kedewasaan perencanaan strategis TI (Van Grembergen, De Haes, dan Guldentops, 2004:16). Dalam situasi ini, memang ada proses yang sama dalam pengelolaan TI di lembaga-lembaga SKPD, tetapi ini bukan berdasarkan suatu standar, tetapi berdasarkan pada kepakaran masing-masing pengelola TI (Butler, 2001:5). Hal ini disebabkan tidak adanya pelatihan formal atau prosedur yang terstandar sehingga tanggungjawab TI terletak pada individual pengelola TI (Solar et al, 2009:5). Walau begitu, proses-proses TI memang telah dikenal dan disiapkan untuk perbaikan ke depannya hingga mencapai level yang lebih baik dan terstandar (de Haes dan van Grembergen, 2004:5). Jika pemerintah menginginkan, sejalan dengan tuntutan perkembangan kebutuhan TI dalam pemerintahan, maka dalam beberapa tahun ke depan, TI di SKPD-SKPD di Kabupaten Minahasa Tenggara dapat berada pada tahap defined process.

Hal lain yang teramati pada evaluasi keseluruhan perencanaan TI adalah aspek yang paling dewasa adalah arsitektur informasi (mean 2,57), diikuti dengan manajemen SDM TI (mean 2,37), dan proses, organisasi, dan hubungan TI (mean 2,32). Aspek yang paling belum dewasa adalah komunikasi tujuan dan arah manajemen (mean 1,79), arah teknologi (mean 1,88), dan manajemen investasi TI (mean 2,12), serta manajemen mutu (mean 2,13). Empat elemen ini merupakan sasaran perbaikan yang dapat diambil oleh pemerintah.

Dilihat secara individual, perencanaan TI secara keseluruhan yang terburuk ada pada Sekretariat DPRD dengan skor total hanya 97, Dinas ESDM dengan skor total 101, dan Dinas PU dengan skor total 109. Sementara itu, perencanaan TI terbaik ada pada BPPKAD (170), Inspektorat (161), dan Sekda (160). Jika dilihat berdasarkan rata-rata, maka hanya DPPKAD yang memiliki prosedur standar karena hanya SKPD ini yang memiliki rata-rata lebih dari 3,00. Dua SKPD terendah memiliki rata-rata yang menyatakan bahwa proses ada tetapi tanpa prosedur, sementara sisanya memiliki prosedur tidak standar.

DPPKAD (Dinas Pendapatan Pengelolaan Keuangan dan Aset Daerah) tampak sebagai satusatunya SKPD dengan TI yang cukup memuaskan. Hal yang mendekati ada pada Inspektorat Daerah dan Sekretaris Daerah. Ketiga badan dapat mewakili masalah keuangan, pengawasan, dan pengelolaan daerah sehingga dengan baik dapat mengelola dalam jumlah besar dalam mendukung fungsi mereka masing-masing. Berdasarkan data ini, dapat dilihat bahwa TI paling membantu bagi pemerintah daerah Minahasa Tenggara dalam penyelenggaraan akuntansi keuangan daerah dalam penerapan akuntansi pembiayaan, peninjauan laporan keuangan Pemda pada tahap perencanaan maupun pelaporan, dan penyediaan barang dan jasa. Sementara itu, TI masih belum efektif dalam menjalankan tugas dalam membantu review oleh wakil rakyat, memberikan masukan dari sektor ESDM dan sektor Pekerjaan Umum. 


\section{KESIMPULAN DAN SARAN}

\subsection{Kesimpulan}

Tujuan penelitian ini adalah mengalamatkan dua isu kunci: bagaimana pelaksanaan sistem pengendalian intern dalam menghasilkan keandalan Laporan Keuangan Pemerintah Daerah dinilai dari kerangka kerja CobiT pada Kabupaten Minahasa Tenggara dan Bagaimana pemanfaatan IT Governance terhadap kehandalan Laporan Keuangan Pemerintah Daerah dinilai dari kerangka kerja yang sama. Jawaban atas permasalahan ini adalah sebagai berikut:

1. Secara keseluruhan, sistem pengendalian intern memiliki nilai rata-rata $68 \%$ yang berarti telah baik. Komponen yang paling baik adalah komponen informasi dan komunikasi (rata-rata 98\%) dan komponen lingkungan pengendalian (rata-rata 81\%). Komponen yang paling buruk adalah komponen aktivitas pengendalian (rata-rata 31\%) dan komponen pemantauan (rata-rata 59\%). Sistem Pengendalian Intern yang membantu Keandalan Laporan Keuangan Pemerintah Daerah diperlukan perbaikan dari segi aktivitas pengendalian dan pemantauan. Dengan menindaklanjuti temuan pemeriksaan dari BPK RI dan Inspektorat Daerah.

2. Secara keseluruhan, pengelolaan IT Governance di SKPD Kabupaten Minahasa Tenggara memiliki skor rata-rata 2,17 yang bermakna masih belum terstandar, walaupun telah memiliki prosedur. Aspek yang paling dewasa adalah arsitektur informasi (mean 2,57), diikuti dengan manajemen SDM TI (mean 2,37), dan proses, organisasi, dan hubungan TI (mean 2,32). Aspek yang paling belum dewasa adalah komunikasi tujuan dan arah manajemen (mean 1,79), arah teknologi (mean 1,88), dan manajemen investasi TI (mean 2,12), serta manajemen mutu (mean 2,13). Empat elemen ini merupakan sasaran perbaikan yang dapat diambil oleh pemerintah. Penyesuaian dengan menambahkan bobot kepentingan aspek meningkatkan skor rata-rata menjadi 2,21 tetapi masih ditafsirkan sama karena tidak terlalu jauh berbeda. Dari penyesuaian dengan bobot ini, ditemukan kalau dua aspek yang paling urgen untuk diperbaiki adalah komunikasi tujuan dan arah manajemen dan manajemen mutu. Analisis dengan pendekatan manajerial menghasilkan kesimpulan bahwa langkah yang paling efektif dan efisien untuk meningkatkan pengelolaan IT Governance di SKPD Minahasa Tenggara adalah optimisasi biaya.

\subsection{Saran}

\subsubsection{Saran untuk Pemerintah Daerah Kabupaten Minahasa Tenggara}

Saran untuk pemda Kabupaten Minahasa Tenggara berdasarkan hasil penelitian ini antara lain:

1. Walaupun aspek rencana strategis TI dipandang sebagai aspek yang paling lemah dari pengelolaan TI di lembaga publik karena orientasi pada keseragaman dengan strategi nasional, pemerintah daerah perlu melakukan sejumlah penyesuaian. Hal ini misalnya disebabkan oleh SKPD dibentuk berdasarkan kewenangan daerah, bukan nasional. Akibatnya terdapat banyak variasi SKPD yang ada di berbagai daerah dengan berbagai kebutuhannya sendiri-sendiri. Kebutuhan yang berbeda memerlukan pula rencana strategis TI yang berbeda. Untuk itu, pemerintah Minahasa Tenggara perlu melakukan tinjauan kembali terhadap pengelolaan TI dan melakukan perbaikan untuk menyusun rencana strategis TI di SKPD-SKPD.

2. Proses, organisasi, dan hubungan TI adalah aspek yang paling kompleks dalam rencana strategis TI. Kinerja aspek ini pada SKPD-SKPD di Minahasa Tenggara sangat beranekaragam yang pada umumnya telah berjalan tetapi tidak terstandar. Pemerintah daerah harus segera membangun standar agar terdapat peningkatan pada dimensi perencanaan TI ini.

3. Hasil evaluasi ini menemukan hanya DPPKAD yang memiliki predikat cukup memuaskan dilihat dari skor perencanaan TI. Karenanya, DPPKAD harus dijadikan contoh sukses terhadap perencanaan TI di kawasan Minahasa Tenggara sehingga dapat ditiru oleh SKPD-SKPD lainnya.

4. Setiap SKPD harus memiliki komite yang memastikan kelincahan organisasi dalam hubungannya dengan penyedia TI dan stakeholder lainnya. Komite ini selain mampu 
membangun jembatan antara SKPD dan masyarakat dalam penggunaan TI, juga dapat digunakan untuk mengatur program pengembangan SDM dalam hal TI di setiap SKPD.

\subsubsection{Saran untuk Penelitian Selanjutnya}

Saran untuk penelitian selanjutnya antara lain:

1. Penelitian ini menggunakan Metode deskriptif dengan analisis framework CobiT dengan kuesioner yang berhubungan instrumen CobiT yaitu Plan and Organize. Untuk penelitian selanjutnya disarankan mencoba ke tahap lainnya seperti Acquire and Implement, Deliver and Support, Monitor and Evaluate, Information Criteria, dan IT Resources.

2. Penelitian ini hanya mendeteksi keadaan di SKPD-SKPD yang ada. Penelitian selanjutnya dapat mengeksplorasi setiap SKPD dalam bentuk studi kasus, khususnya pada DPPKAD sebagai kasus sukses dan SKPD-SKPD lain yang sedang dan gagal.

3. Terakhir, penelitian selanjutnya dapat meneliti sampel dalam jumlah yang lebih besar sehingga memperoleh gambaran untuk Sulawesi Utara secara keseluruhan.

\section{DAFTAR PUSTAKA}

Azhar. 2007. Faktor-faktor yang Mempengaruhi Keberhasilan Penerapan Permendagri Nomor 13 Tahun 2006 Pada Pemerintah Kota Banda Aceh. Tesis. Pascasarjana Universitas Sumatera Utara, Medan.

Badan Pemeriksa Keuangan RI. 2006. Konsep Standar Pemeriksaan Keuangan Negara.

RI , 2008 Laporan Hasil Pemeriksaan Kab. Minahasa Tenggara Tahun Anggaran 2008 BPK RI

Butler, R.J. 2001. Applying the CobiT® Control Framework to Spreadsheet Developments. Controlling the Subversive Spreadsheet - Risks, Audit and Development Methods Proceedings of EuSpRIG 2001 Conference

Darise, Nurlan. 2008. Akuntansi Keuangan Daerah (Akuntansi Sektor Publik). Jakarta : PT Indeks

Darise, Nurlan. 2009. Pengelolaan Keuangan Daerah. Jakarta : PT Indeks

Diskominfo Jawa Timur. 2014. Ubaya Lakukan Studi Ekskursi ke Kominfo Jatim. http://kominfo.jatimprov.go.id/watch/40472

Herminingsih. 2009. Pengaruh Partisipasi dalam Penganggaran dan Peran Manajerial Pengelola Keuangan Daerah terhadap Kinerja Pemerintah Daerah. Tesis S2 Program Pasca Sarjana Magister Akuntansi, Universitas Diponegoro Semarang.

Hill, P., Turbitt, K. 2006. Combine ITIL and COBIT to MeetBusiness Challenges. BMC software best Practice White Paper

Nasution, Anwar 2008 .Perbaikan Pengelolaan Keuangan dalam Era Reformasi http://www.slideshare.net/banglarangan/dialog-publikmanado diakses 1 Mei 2014

Oktari, Ranti, 2011. Pengaruh Pemanfaatan Teknologi Informasi dan Pengendalian Intern Terhadap Kinerja Instansi Pemerintah Daerah, Skripsi. Universitas Riau.

Panko, R.R. 2006. Spreadsheets and Sarbanes-Oxley: Regulations, Risks, and Control Frameworks. Communications of the AIS, Vol. 17, Article 29

Republik Indonesia, Undang-Undang Nomor 17 Tahun 2003 tentang Keuangan Negara. Indonesia.

\section{Keuangan Daerah}

Pemerintah

Pemerintah

Simonsson, M., Johnson, P. 2006. Assessment of IT Governance - A Prioritization of Cobit. KTH, Royal Institute of Technology 
Slaughter, S.A., Ang, S., Boh, W.F. 2007. Firm Spesific Human Capital and Compensation Organizational Tenure Profile: an Archival Analysis of Salary Data for IT Professionals. Human Resource Management, 46(3):373-394

Solar, M., Astudillo, H., Valdes, G., Iribarren, M., Concha, G. 2009. Identifying Weaknesses for Chilean eGovernment Implementation in Public Agencies with Maturity Model. Universidad Técnica Federico Santa María

Spremic, M. 2009. IT Governance Mechanisms in Managing IT Business Value. WSEAS Transactions on Information Science and Applications, 6(6):906-915

Tuttle, B., Vandervelde, S.D. 2007. An empirical examination of CobiT as an internal control framework for information technology. International Journal of Accounting Information Systems 8 (2007) $240-263$

Van Grembergen, W., de Haes, S., Amelinckx, I. 2003. Using COBIT and the Balanced Scorecard as Instruments for Service Level Management. Information Systems Control Journal, 4

Valdes, G., Solar, M., Astudillo, H., Iribarren, M., Concha, G., Visconti, M. 2011. Conception, development and implementation of an e-Government maturity model in public agencies. Government Information Quarterly 28 (2011) 176-187 